\title{
O MTST E O PMCMV: O “PODER POPULAR” PRÓPRIO AO LULISMO
}

\author{
ISADORA DE ANDRADE GUERREIRO
}

USP. Doutorado em Arquitetura e Urbanismo. CV: http://lattes.cnpq.br/9114466250378125

Artigo submetido em Junho/2016 e aceito em Julho/2016

\section{RESUMO}

A produção do espaço realizada por movimentos populares por meio do Programa Minha Casa Minha Vida (PMCMV) - Entidades é uma entrada privilegiada de reflexão acerca do lulismo, pois dá conta de certa totalidade do processo social na qual estão imbricadas determinações econômicas, políticas, sociais e culturais. Nestes termos, apresentamos um estudo de caso específico, a partir do qual são retirados elementos para tal reflexão: os conjuntos João Cândido e Chico Mendes, localizados em Taboão da Serra-SP, realizados pelo Movimento dos Trabalhadores Sem Teto (MTST). Tanto o processo de projeto quanto a forma urbana cristalizada são expressões de determinada ressonância entre o sistema de gerenciamento político lulista - que dá forma à função dependente do Brasil no mercado mundial - e uma organização popular que cresce se apoiando no sujeito político consumidor forjado nesta conjuntura. São elementos que colocam questionamentos acerca da potencialidade transformadora deste tipo de arranjo político e social, no qual a aliança dos trabalhadores se dá com o capital em nome da criação de certo "poder popular" distante da formação do sujeito político autônomo, produtor de um novo programa para as cidades.

PALAVRAS-CHAVE: Lulismo. MTST. PMCMV. Produção do espaço.

\section{ABSTRACT}

The production of space conducted by popular movements through the "Programa Minha Casa Minha Vida (PMCMV)" - Entities gives us prime insights to reflections about the Lulism since this spatial production realizes certain totality of social processes in which are embedded economic, political, social and cultural determinations. Accordingly, we present a specific case study, from which we can draw elements for such reflection: the housing "João Cândido" and "Chico Mendes", located in Taboão da Serra-SP, conducted by the Homeless Workers Movement (MTST). Both the project process and the crystallized urban form are expressions of a certain resonance between the political management system of the Lulism - shaping Brazilian dependent function on the world market - and a popular organization that grows based on consumer political subjects, wrought in the mentioned conjuncture. These are elements that pose questions about the transformative potential of this kind of political and social arrangement, in which the alliance of workers with capital is justified by creating a "popular power" away from the formation of the autonomous political subject, producer of a new program for cities.

Keywords: Lulism. MTST. PMCMV. Production of space. 


\section{INTRODUÇÃO}

Assistimos, neste momento do país, à crise de um modelo de gerenciamento da política que amadureceu e frutificou durante o governo do PT, denominado de "Iulismo"1 (ainda que o termo e os conceitos internos a ele sejam bastante polêmicos e suscitem discordâncias entre pesquisadores). Numa articulação complexa, o lulismo transformou relações econômicas, políticas, sociais, culturais, etc., sendo de difícil apreensão em sua totalidade. $\mathrm{O}$ trabalho aqui proposto procura se aproximar desta totalidade por meio da análise da produção do espaço urbano por organizações populares, formulando a hipótese de que o Programa Minha Casa Minha Vida (PMCMV) deve ser entendido como instrumento específico desta forma gerencial. Interessa analisar as relações entre tal gerenciamento e a formatação do programa, particularmente quanto à sua incidência junto aos movimentos populares de luta pela moradia.

O lulismo tem formulações divergentes na bibliografia no que tange à dinâmica de classes. No entanto, há certo consenso em torno da constatação de que se baseia na gestão social e política da conciliação de classes, apagamento da política e fortalecimento do papel brasileiro nos marcos da divisão internacional do trabalho sob o capital. Interessa aqui compreender seu significado na medida em que forja um sujeito político que, de forma contraditória, só entende os processos de autonomia dentro dos parâmetros do capital pois é incluído no sistema por meio da sua face de consumidor. Esta autonomia, longe da autogestão defendida por setores populares na década de 1980, expressa-se na relação de disputa individual de pequenos privilégios, poder local e concessões do poder público, sempre na forma de recursos precários para a magnitude do processo, mas amplamente suficientes para a desarticulação das relações comunitárias e propriamente políticas. Neutraliza-se a direção, aloca-se o empreendedorismo como atitude política e precarizam-se os processos produtivos autônomos, a partir dos quais seria possível reestruturar o trabalho de base.

A forma democrática petista, elemento que estrutura o lulismo, amadurece por meio da consolidação de um modo específico de subsunção do Estado ao capital, que responde às necessidades das formas fictícias deste atual estágio de desenvolvimento mundial com funções particulares para os países periféricos. Segundo Leda Paulani, esta função seria a de "plataforma de valorização financeira internacional", renovando seus laços de dependência e desigualdade social estrutural mantidos pela elite nacional. Este gerenciamento exige a profissionalização do controle da luta de classes, dando vida útil a uma das principais habilidades do lulismo. Uma nova estratificação social é conformada a partir da ação estatal, a qual segmenta e profissionaliza as lideranças que lhe darão voz.

\footnotetext{
${ }^{1}$ O termo "Iulismo" foi cunhado por Rudá Ricci em 2004 (compilado em RICCI: 2013 [2010]), mas amplamente difundido depois da publicação de "Os sentidos do Lulismo" de André Singer em 2012, principalmente para o meio paulista. Os autores que discutiram o conceito foram, além dos dois citados, principalmente: Luiz Werneck Vianna, Marcos Nobre, Ruy Braga, Márcio Pochmann, Jessé Souza, Tales Ab'Saber e Marcelo Neri. No entanto, a questão da especificidade da gestão Lula e do PT já estava na academia desde 2003, por meio das pesquisas de Francisco de Oliveira, Leda Paulani, Marilena Chauí, Lincoln Secco, Carlos Nelson Coutinho e Mauro lasi, dentre os mais citados.
}

Dialektiké, v. 1, 2016. p. 52-78 
O PMCMV é entendido aqui como uma das partes constitutivas da estrutura institucional do lulismo, na medida em que opera, a partir do Estado, relações entre o mercado de capitais, o mercado de terras, o setor produtivo (setor imobiliário) e a dinâmica de classes. Tal mediação é feita por meio da produção da casa e da cidade como mercadoria, tecendo redes potentes de amoldamento social e político, pois vinculadas diretamente ao elemento mais custoso da reprodução da força de trabalho. Há a conformação de uma estrutura operacional específica, interna ao Estado, que atualiza os modos de subsunção do trabalho ao capital, construindo conexões com o setor produtivo, o qual é induzido à alteração de sua cadeia técnico-produtiva sem a necessidade da intervenção direta do Estado no setor (como ocorria na regulação nacional-desenvolvimentista). As determinações do programa em relação ao acesso à terra, financiamento, lógica produtiva, legalidade institucional, etc. são instrumentos deste amoldamento e direcionamento das táticas das forças sociais.

Dentro desta perspectiva, a porcentagem do programa reservado às "Entidades" não pode ser entendida como uma exceção à lógica que determina sua totalidade. A própria conformação do movimento popular à figura da "Entidade" deve ser compreendida no âmbito da profissionalização e institucionalização das forças sociais, que devem seguir uma série de pré-requisitos burocráticos, ter recursos financeiros próprios e apresentar corpo técnico para poderem acessar o programa. Da mesma maneira que o Estado induz a transformação do setor produtivo, também amolda certos movimentos populares, criando um cenário não de cooptação, mas de conformação: ao invés de trazê-los para dentro da instituição, potencializa sua ação de maneira controlada e subsumida na medida em que estimula formas (dinâmicas) similares à sua - a forma Estado, simétrica à forma Capital. A massificação destes movimentos não pode ser entendida, portanto, como um aprofundamento direto da consciência de classe ou uma radicalização política, mas sim como resultado da sincronia com uma forma dominante socialmente, o próprio capital, na especificidade brasileira.

A hipótese aqui proposta é a de que o PMCMV conforma determinada dinâmica para a luta de classes a partir da lógica que o estrutura, moldando a ação dos movimentos populares não através de cooptação, mas de potencialização de certos interesses comuns através de instrumentos de conformação, que transmutam elementos originalmente conflituosos em negociáveis ao traduzi-los para a linguagem consensual. Uma consolidação de uma democracia estranha, pois avessa ao conflito dissensual. Esta noção pode ser encontrada em Rancière:

O que o autor [Jacques Rancière] chama, então, de 'pós-democracia', caracteriza-se pelo avesso da democracia real: ela é a 'prática consensual do apagamento das formas do agir democrático'. É a prática governamental de uma democracia depois do demos, que liquidou (...) o litígio do povo, redutível aos dispositivos do Estado e das composições de interesses sociais. É um modo de identificação entre os dispositivos institucionais e a disposição das parcelas da sociedade: o desaparecimento do sujeito e do agir próprio da democracia, sendo a adequação total entre as formas do Estado e o estado das relações sociais. É, portanto, a democracia consensual: 'Consenso é um certo regime do sensível. É o regime em que as 
partes já estão pressupostamente dadas, sua comunidade constituída (...). $O$ que o consenso pressupõe portanto é o desaparecimento de toda distância entre a parte de um litígio e a parte da sociedade. (...) É, em suma, o desaparecimento da política'. (GUERREIRO: 2006, 130).

Esta "pós-democracia" pode ser facilmente identificada no gerenciamento consensual da política praticado pelo lulismo. A forma do amoldamento de certas organizações populares que é aprofundada por este modo gerencial de governo é uma de suas faces mais perversas, que se expressa no avanço da subsunção destes movimentos ao capital, pois neles se configura, conjunturalmente, uma lógica expansionista baseada no domínio do território por meio da produção habitacional como mercadoria. Tais movimentos deixam de intervir nas relações de produção e na formação política de militantes, concentrando sua ação nos ganhos políticos advindos da disputa da terra dentro dos marcos do capital. Tal ação resulta em massificação e poder social baseado nas estruturas espetaculares internas à forma mercadoria.

Do lado do movimento, constitui-se uma técnica de liderança profissional para lidar com uma das frações de classe organizadas pelo lulismo, que quer o acesso às políticas públicas sem a necessidade de engajamento político na esfera produtiva. Agem como consumidores que anseiam urgentemente mercadorias prontas no mercado, pervertendo tanto a figura do cidadão de direito quanto a do sujeito político autônomo. O déficit habitacional - denunciado em seu discurso - é utilizado como base de crescimento político, criando uma relação com a base (entendida como "demanda") que assimila a forma do mercado. Interesses compatíveis, Estado e movimento potencializam suas ações por meio do PMCMV.

O objeto de estudo assim delimitado - a subsunção da ação dos movimentos populares de luta pela moradia pelo lulismo por meio do PMCMV - será exposto a partir de um caso de particular relevância para o processo de massificação de um dos movimentos populares que mais cresceu nacionalmente no último período - o Movimento dos Trabalhadores Sem Teto (MTST). Trata-se dos empreendimentos habitacionais João Cândido e Chico Mendes em Taboão da Serra (SP), que somam 1.024 unidades habitacionais (UHs) realizadas através da modalidade Entidades/Empreitada Global ${ }^{2}$ do PMCMV $^{3}$.

\section{MTST E O LULISMO}

\footnotetext{
2 O PMCMV-Entidades é uma parte do programa vinculada aos recursos do FDS (Fundo de Desenvolvimento Social), que faz contratações diretamente com Entidades habilitadas no Ministério das Cidades para a construção habitacional. As entidades têm autonomia de contratação de projeto, assessoria técnica e escolha da demanda. Elas podem escolher entre a modalidade Empreitada Global (na qual os recursos são repassados integralmente a uma construtora) ou a Autogestão (na qual gerem diretamente os recursos e podem contratar mão de obra, realizar mutirão ou contratar trabalho cooperativado, além de fazer autonomamente a compra dos materiais e gerir o cronograma de obra).

${ }^{3}$ As fontes que lastreiam este estudo de caso, além das referências bibliográficas, são baseadas em experiência pessoal direta e entrevistas com técnicos da prefeitura, militantes e ex-militantes do MTST. Para garantir a fluidez do texto e a preservação da identidade dos entrevistados, não foram colocadas suas referências diretas.
}

Dialektiké, v. 1, 2016. p. 52-78 
Fundado em 1997, a partir da saída de militantes do Movimento dos Trabalhadores Sem Terra (MST), o MTST se apresentou na primeira década deste século como uma alternativa na luta urbana da Grande São Paulo, principalmente a de moradia, em relação a outros movimentos populares originados no bojo da redemocratização, junto ao PT. Sem raízes no trabalho de base inspirado pela igreja católica ${ }^{4}$, a organização nasce numa outra conjuntura, na qual se consolidam as críticas aos rumos tomados pelo campo político conformado pelo Projeto Democrático Popular (PDP), consolidado em 1987 no 5o Encontro do PT. Esta conjuntura inclui a radicalização das contradições e conflitos urbanos (materializados no quase esgotamento da extensão territorial periférica), os quais configuraram novas e mais violentas relações sociais. Forças sociais antes menores passaram a ter predominância na organização do cotidiano e da correlação de forças da periferia, principalmente através do crescimento e consolidação das igrejas evangélicas neopentecostais, da organização centralizada do tráfico de drogas a partir do Primeiro Comando da Capital (PCC, fundado em 1993) e de uma ação estatal que passa a executar mudanças legislativas e práticas institucionais herdeiras da redemocratização e devedoras, diretamente, do campo democrático popular.

O MTST se configurou - e carrega esta origem - como uma organização que se poderia caracterizar como "de transição", pois carrega uma série de práticas e retórica crítica dos tradicionais movimentos de moradia em relação à pauta da Reforma Urbana, ainda que se afaste delas na sua metodologia e objetivos políticos. Sua organização interna, devedora do centralismo democrático do MST, é pouco afeita à horizontalidade decisória e descentralização do poder na base, que objetiva a formação de um sujeito político autônomo. No entanto, suas primeiras ocupações (na primeira metade dos anos 2000) foram organizadas de maneira muito próxima às dos tradicionais movimentos de moradia. No momento em que foram feitas (na Grande São Paulo), a discussão de moradia na capital estava focada na questão da área central da cidade e seus imóveis vazios, na retomada do programa de mutirões, além de políticas alternativas à provisão habitacional, como o aluguel social e a urbanização de favelas.

O MTST recoloca, portanto, de maneira bastante polêmica naquele momento no meio militante, a necessidade de organizar a periferia como território que é a materialização da identidade da "nova" classe trabalhadora (anterior à lulista), precarizada e espoliada, sem acesso ao trabalho formal e que, portanto, não tem sua identidade política na organização do trabalho. Era um movimento pequeno, porém reconhecido (principalmente dentro da Universidade) por deflagrar novamente conflitos urbanos por meio de ocupações de terra e bloqueio de rodovias, ações diretas das quais o movimento de moradia tradicional se afastava ao direcionar sua atuação para a formulação e execução de políticas públicas. Sua atuação com base na periferia também fazia com que não se considerasse um movimento de moradia, mas uma organização popular identificada com a questão urbana.

O MTST é um movimento que organiza trabalhadores urbanos a partir do local em que vivem: os bairros periféricos. Não é nem nunca foi uma escolha dos trabalhadores morarem nas periferias; ao contrário, o modelo

${ }^{4}$ Os movimentos populares ligados ao trabalho de base originados na época da redemocratização têm inspiração e vinculação direta com as Comunidades Eclesiais de Base (CEBs).

Dialektiké, v. 1, 2016. p. 52-78 
de cidade capitalista é que joga os mais pobres em regiões cada vez mais distantes. Mas isso criou as condições para que os trabalhadores se organizem nos territórios periféricos por uma série de reivindicações comuns. Criou identidades coletivas dos trabalhadores em torno destas reivindicações e de suas lutas. Ao mesmo tempo, a organização sindical, no espaço de trabalho, tem tido enormes dificuldades em organizar um segmento crescente de trabalhadores (desempregados, temporários, terceirizados, trabalhadores por conta própria, etc.), a partir de transformações ocorridas no próprio processo produtivo, que tornaram as relações trabalhistas mais complexas e diversificadas. Assim, o espaço em que milhões de trabalhadores no Brasil e em outros países têm se organizado e lutado é o território. É aí que o MTST se localiza: Somos um movimento territorial dos trabalhadores ${ }^{5}$.

Esta posição frente ao urbano se alinhava com um período de ascensão dos movimentos anti-globalização, que se afastavam das reivindicações por políticas públicas ou negociações sindicais e elegiam a rua, a cidade, como palco do conflito. Trata-se de um período (final dos anos 1990) de consolidação das consequências do neoliberalismo mundialmente. David Harvey é um dos teóricos que refletirá sobre estes novos movimentos, articulando sua ascensão com uma mudança na forma de expansão do capital que, depois de 1973, segundo ele, muda de uma predominância de reprodução expandida para outra de "acumulação por espoliação" (HARVEY: 2004). Este conceito está assentado na perspectiva da necessidade de subordinação real, pelo capital, de elementos ainda articulados a ele de maneira formal, como alternativa para continuar sua expansão. Seria uma espécie de acumulação primitiva permanente, integrando à forma capital relações locais cuja dinâmica se baseava em outros critérios de validação social. A espoliação, portanto, seria um mecanismo do capital de expropriação de saberes, modos de vida, instituições, direitos, formas de propriedade primitivas, culturas, economias locais, relações de produção, etc., que, para Harvey, resultam numa vida urbana transformada em barbárie.

O MTST se colocava, no início dos anos 2000 , nesta perspectiva de ação política em torno dos conflitos urbanos decorrentes do aprofundamento da espoliação, que se dá de maneira particular nos países dependentes. Combina, assim, elementos característicos de uma nova fase de articulação da esquerda, porém sem trazer junto sua organização horizontal ligada à formação do sujeito político autônomo. Seu direcionamento não é para este sujeito, nem para a contribuição na formulação de políticas públicas num "aperfeiçoamento" da democracia junto ao PT. Sua estratégia política se baseia no domínio do território e na mobilização da massa espoliada como instrumento político, a ser utilizado em negociações dentro do Estado como meio de expansão. O "poder popular", nestes termos, é poder territorial, sem que isso signifique a produção de um espaço próprio dos trabalhadores. Partindo do déficit habitacional, o MTST usa como instrumento de luta as ocupações de terras ociosas nas periferias, sem uma demanda organizada prévia. O caráter destas ações é de mobilização de grandes contingentes de famílias por meio da ocupação territorial.

${ }^{5}$ Fonte: http://www.mtst.org/quem-somos/as-linhas-politicas-do-mtst/ acessado em 22 de maio de 2016.

Dialektiké, v. 1, 2016. p. 52-78 
Desta maneira, essa metodologia já diferia dos movimentos de moradia tradicionais paulistanos, formados a partir da herança metodológica das CEBs, na qual o trabalho de base está no centro da ação política, objetivando a construção de poder popular a partir da auto-organização e conscientização subjetiva. Nestes termos, a luta por moradia estava inserida numa estratégia de acúmulo de forças (parte do PDP), cujo papel era o de se aproximar e formar as bases. Neste processo estavam incluídos os Grupos de Origem, a ocupação de terra, a pressão junto ao poder público e a realização direta do projeto das novas unidades habitacionais, a gestão e parte da execução de sua obra, além da organização de pós-ocupação.

No caso do MTST, pelo contrário, as ocupações têm a característica de crescerem exponencialmente nos primeiros dias, com a adesão de grande número de pessoas ou famílias sem vinculação anterior com o movimento, convocadas por carro de som. A expressão física deste método revela grandes extensões de terra periférica com barracos de lona preta na forma de tendas diminutas com tamanho especificado e que não têm função de abrigo. São identificações territoriais, numeradas segundo um cadastro. Imageticamente é criado um cenário impressionante, que referencia famílias a estruturas precárias de lona preta. A conhecida fila da prefeitura (o cadastro do déficit habitacional feito pelo Estado) tem aqui sua lógica estrutural reposta pela presença material do cadastrado por meio de seu representante abstrato: a unidade territorial de lona preta. $\mathrm{O}$ sujeito político é caracterizado como aquele que se apresenta, de corpo presente ou representado, porém como unidade abstrata material, sem voz própria ${ }^{6}$.

Tal estratégia política baseada em domínio territorial teve limitações claras, desde o início do movimento, na medida em que as ocupações foram reintegradas sem a conquista da moradia definitiva. Isso não era uma questão tão relevante nos primeiros quase 10 anos, quando se tratava de uma organização local e preocupada com a construção de poder popular na base que, embora reunida de maneira pouco qualitativa, passava, necessariamente, por um processo de formação política ao vivenciar a estrutura organizativa coletiva no cotidiano da ocupação. Era uma situação inclusive buscada ativamente pelas lideranças, pois havia muita autonomia em relação às instituições e organizações já estabelecidas (partidos, sindicatos, etc.), embora poucos recursos para a manutenção dos quadros e ações, o que impedia também seu crescimento. Pesada a conjuntura no segundo mandato de Lula, a avaliação do movimento, depois de 2006, foi de que esta estratégia se esgotava ao não oferecer nenhuma conquista material à base.

Note-se desde já a especificidade dessa mudança e sua conjuntura histórica. Ficava claro às lideranças que o modelo tradicional de trabalho de base não frutificava como há trinta anos. Tratava-se de outra constituição histórica material e subjetiva da classe trabalhadora, particularmente a base social do movimento, com identidade de classe não formada nas relações de produção, mas no território periférico. Uma população extremamente precarizada, que vive diretamente as consequências da espoliação urbana que avançou no último período, principalmente no custo da terra (moradia) e do transporte.

\footnotetext{
${ }^{6}$ A semelhança com a forma mercadoria é relevante: "A riqueza das sociedades em que domina o modo de produção capitalista aparece como uma 'imensa coleção de mercadorias' e a mercadoria individual como sua forma elementar" (MARX: 1983 [1867], 45. Grifo acrescido).
}

Dialektiké, v. 1, 2016. p. 52-78 
Diferente do sujeito político periférico e espoliado da década de 1980 , este é forjado pelo Iulismo:

\begin{abstract}
Constituindo, desde o alto, o subproletariado em suporte político, o lulismo repete mecanismo percebido por Marx em 018 de Brumário. A análise de Marx é que as frações de classe que demonstram dificuldades essenciais para se organizar e tomar consciência de si, como já vimos, apresentam-se na política enquanto massa. Destituída da possibilidade de agir por meios próprios, a massa se identifica com aquele que, desde o alto, aciona as alavancas do Estado para beneficiá-la (SINGER: 2012, 36-37).
\end{abstract}

E, mais a frente: "A proposta de auto-organização para a luta política de classes, que estava no âmago dos grupos que formaram o PT na década democrática (1978-88), não foi assumida pelo governo Lula" (SINGER: 2012, 188). Este sujeito político entendido enquanto massa é forjado como sujeito consumidor na esteira da ampliação do mercado interno brasileiro. Quer mercadorias como direitos, que devem vir por meio daqueles que "acionam as alavancas do Estado para beneficiá-lo": o movimento popular, aquele mesmo que se nacionaliza por meio do PMCMV, constrói habitação como mercadoria, e se massifica, pois adapta sua estratégia política a este sujeito político, não àquele forjado no trabalho de base.

\title{
3 O URBANO COMO MERCADORIA POLÍTICA
}

A história dos empreendimentos João Cândido e Chico Mendes, no Jardim Salete, em Taboão da Serra, é bastante longa, complexa e enseja uma série de questões para o embasamento da hipótese defendida por este trabalho. Não serão abordados todos os momentos e elementos que esgotariam o tema. A exposição dará luz a situações chave que costuram uma narrativa aparentemente contraditória, mas que oferece elementos importantes para a hipótese de ressonância entre formas semelhantes que se potencializam: o lulismo e o movimento popular vinculado a um sujeito político tão abstrato quanto a forma mercadoria.

A área do Jardim Salete foi negociada junto à Companhia de Desenvolvimento Habitacional e Urbano (CDHU), vinculada ao Estado de São Paulo, como resultado de cerca de dois anos de negociações entre a Prefeitura Municipal de Taboão da Serra (PMTS), sob gestão de Evilásio Cavalcante de Farias (PSB), o governo do Estado (PSDB), o MTST e o MSTTS $^{7}$. A tática assumida pelo MTST entre os anos de 2006 e 2008 nesta cidade foi a de articular forças político-partidárias, com o objetivo de efetivar um grande empreendimento habitacional, avaliado como elemento necessário à meta de massificação do movimento. Esta articulação envolvia, junto à prefeitura, a pressão pela conquista de terra e, junto ao

\footnotetext{
${ }^{7}$ Movimento Sem Terra de Taboão da Serra: movimento local de famílias vinculadas a Paulo Félix, liderança que também exercia o cargo de vereador naquele momento (2006-2008) pelo PSDB. Ele teve seis mandatos consecutivos em Taboão da Serra (desde 1983), e foi até 1995 filiado ao PT, depois ao PSDB e, desde 2011, ao PMDB.
}

Dialektiké, v. 1, 2016. p. 52-78 
Estado, financiamento e produção das unidades habitacionais ${ }^{8}$. As duas esferas de governo, geridas por forças políticas antagônicas, foram acionadas e colocadas em enfrentamento por meio do método de ação política do MTST, que envolve ação direta em manifestações, fechamento de rodovias, ocupação de terras e sedes administrativas, combinada com mesas de negociação pautadas pelo acirramento da correlação de forças. O MTST se associou ao MST-TS na perspectiva de iniciar uma relação estratégica com a CDHU (através do PSDB), ponte importante de apoio na expansão estadual do movimento, meta daquele momento (entre 2006 e 2009).

A desapropriação do terreno do Jardim Salete, em setembro de 2008, foi realizada diretamente pela CDHU para a demanda habitacional conjunta dos dois movimentos, ainda que fosse uma área com $80 \%$ de zoneamento industrial e a quantidade de famílias envolvidas não fosse oficialmente clara ${ }^{9}$. No entanto, a negociação do terreno foi realizada para um montante de cerca de 1.000 famílias, dada a massificação que o MTST alcançou nas ofensivas de 2007 e 2008, particularmente na região sudoeste da Grande São Paulo. A principal delas foi a Ocupação João Cândido, na divisa de Itapecerica da Serra (município vizinho) com o Valo Velho, em São Paulo, que depois foi deslocada para a Vila Calú (em Itapecerica). O município de Embu das Artes, com gestão do PT desde 2000 (até a presente data), também teve a Ocupação Silvério de Jesus, em 2008. Isso fez com que a PMTS, numa gestão que deu especial relevância à urbanização de favelas e à produção habitacional junto a movimentos organizados, identificasse o movimento como "estrangeiro" tendo sérias críticas e dificuldades de lidar com sua tática de enfrentamento que, no limite, não era considerada uma proposta de reforma urbana, mas de conquista material. Segundo a secretária de habitação, o MTST queria "exclusividade"10 e desviava, portanto, das questões municipais e relações locais de conflito urbano, em nome da articulação nacional.

É importante notar que, mesmo com o apoio da poderosa e rica CDHU, foi descartada pelo MTST a alternativa de lutar pela desapropriação da área originalmente ocupada na cidade, a Ocupação Chico Mendes, que ocorreu em 2005. Ainda em momento de consolidação do desejado patamar de reconhecimento social e político nacional (ou mesmo estadual), o movimento ainda dependia de relações locais, que foram efetivadas por meio de relações parlamentares e articulações internas aos órgãos públicos. Suas pautas seguiram cada vez mais este caminho, conformando a prática de ocupações midiáticas sem o objetivo imediato de moradia e, na maioria das vezes, sem o objetivo mesmo de disputar a área específica ocupada. Isso torna a desocupação um momento político fundamental, na medida em que é ali que se efetiva a rede de relações com o aparato estatal. Gozando de autonomia partidária, o MTST conseguiu trânsito entre as mais diversas tendências políticas, por conta da sua capacidade de mobilização de massa, grande trunfo político na era espetacular.

\footnotetext{
${ }^{8}$ Neste momento o PMCMV ainda não existia (seu lançamento é de 2009), e as possibilidades de construção de moradia se davam ou por meio da CDHU (em empreitada global); ou no Programa Crédito Solidário, do governo federal, direcionado às Entidades e origem do desenho do PMCMV-E; ou ainda pelo Programa Operações Coletivas do FGTS, Resolução 460, que foi pioneiro no atendimento às famílias de 0 a 3 salários mínimos, por prever grande porcentagem de subsídio.

9 O MTST tinha, em 2006, uma demanda cadastrada em Taboão da Serra de 250 famílias, oriundas da Ocupação Chico Mendes, de 2005. Em 2008, quando o terreno do Jardim Salete foi desapropriado, havia 102 famílias com auxílio-aluguel ligadas ao MTST na cidade.

${ }^{10} \mathrm{Cf}$. CAMARGO: 2016.
}

Dialektiké, v. 1, 2016. p. 52-78 
O ano de 2009 foi especial para esta conjuntura. Desde 2005 como Ministra-Chefe da Casa Civil, Dilma Rousseff comanda o amadurecimento do lulismo por meio de transformações técnicas internas ao Estado. Em 2009 tal estrutura teve que ser colocada em modo de emergência máximo por conta da crise internacional, sintonia esta bastante característica do neoliberalismo dependente ${ }^{11}$.

Em 2009 há uma transição importante neste aspecto: ao mesmo tempo em que se consolida uma série de apostas e metas do segundo mandato de Lula, também se radicaliza o estado de emergência econômico, expresso em medidas anticíclicas. É dentro dessa conjuntura que o PMCMV é lançado pela Casa Civil, passando por cima do Plano Nacional de Habitação (PlanHab) formulado durante dois anos dentro do Ministério das Cidades e lançado no mesmo ano. Ainda que com críticas, os movimentos populares abraçaram o PMCMV na sua modalidade Entidades, deixando o PlanHab em segundo plano e, em curtíssimo espaço de tempo, esquecido como pauta de reivindicação. Perde-se aí a possibilidade de um planejamento habitacional em âmbito federal, que continha uma série de alternativas diversas para atacar o problema.

O PMCMV, como solução única de construção de unidades novas em terra de mercado, sem planejamento estatal nem controle social, é adotado tanto pelo setor imobiliário quanto pelos movimentos de moradia que, mesmo com críticas ao programa, abraçam sua solução única, na qual também são agraciados. A contradição aqui fica bastante clara: ainda que o movimento de Reforma Urbana tenha levantado as questões de edifícios e terrenos vazios, urbanização de favelas e locação social, os movimentos de moradia que mais se fortaleceram e cresceram politicamente foram aqueles que apostaram na construção de novas unidades. Assim, as críticas em relação ao programa sempre levaram ao consenso em torno do seu "aperfeiçoamento", mas não à sua insuficiência (entre outros problemas).

Esta conjuntura abre um enorme espaço para a prática política do MTST e sua meta de nacionalização, com inserção de enorme montante de recursos para a compra de terras e "conquistas materiais" para a base. Se a CDHU foi instrumento de estadualização, o PMCMV foi o de nacionalização: com a entrada privilegiada (por conta do seu domínio de demanda) no mecanismo interno do Estado, o movimento passa a ter abertura em diversas comunidades e organizações políticas no país, pois possui o trunfo de mediar o acesso às políticas sociais do governo. É neste mesmo ano de 2009 que o movimento faz seu I Encontro Nacional, e também é lançada a Resistência Urbana - Frente Nacional de Movimentos Urbanos, da qual faz parte junto com organizações urbanas de oito estados, sendo seu protagonista.

O empreendimento do Jardim Salete está inserido diretamente neste ano importante para o MTST, pois era seu cartão de visitas que o valorava frente à base e às outras organizações, além de também ser sua entrada direta de relações dentro do Estado. No primeiro semestre de 2009, CDHU e PMTS são acionadas nas articulações para a execução do projeto arquitetônico e urbanístico da área que, depois de ser grafada como Zona Especial de Interesse Social (ZEIS), exigia um grande e difícil adensamento, que sempre

11 “(...) se pode dizer que, a partir do Plano Real, há um sentimento difuso de 'emergência econômica'. Trata-se de uma espécie de estado de exceção econômico que vai sendo paulatinamente decretado e que justifica qualquer barbaridade em nome da necessidade de salvar o país" (PAULANI: 2008, 135).

Dialektiké, v. 1, 2016. p. 52-78 
foi polêmico em HIS. Os dois órgãos desenvolveram estudos rápidos: a CDHU com seu padrão universal e a PMTS propondo um desenho de maior qualidade urbanística e arquitetônica, numa solução original (não padronizada). O MTST, apoiado no direcionamento da assessoria técnica Usina-CTAH ${ }^{12}$, pressiona para que o projeto seja original e realizado através da PMTS.

\section{UM PROJETO DE CIDADE: A CONSOLIDAÇÃO DA EXPERIÊNCIA JUNTO AOS TRABALHADORES}

O trabalho da Usina, desde sua fundação em 1990, sempre foi o de repensar as relações de produção da cidade, dentro de um processo de transformação social junto a movimentos populares no qual se articulam a autogestão da produção e a qualidade no projeto oriunda de sua formulação direta pelos trabalhadores e suas necessidades. Longe, portanto, da questão da habitação como eliminação de déficit. O Jardim Salete representava um ponto de inflexão nesta trajetória de relação com movimentos populares e sua produção qualitativa de cidade e de organicidade. A produção habitacional, para o MTST, estava dentro de uma estratégia política bastante diversa, pautada pela necessidade de domínio territorial e de demanda entendidos como instrumentos de acirramento da correlação de forças no enfrentamento com o Estado e com os representantes do capital, por meio das mesas de negociação e da mídia. Desta perspectiva, esta fase de expansão do movimento foi marcada por um afastamento do trabalho de base e organização cotidiana das ocupações, que passaram a ser referências simbólicas e territoriais.

Portanto, há uma mudança fundamental na forma política. O modelo anterior, representado historicamente pela Usina, direcionava a ação de transformação para as relações de produção do urbano, sendo seu produto uma expressão delas, seu sujeito uma força social ativa, além do território apropriado, centro irradiador político e materialização de uma cidade pensada e construída pelos trabalhadores. As contradições e limites históricos que esta forma política tomou ao assumir a autogestão como uma ferramenta de transformação interna ao Estado (levadas adiante pelos tradicionais movimentos de moradia) são bastante conhecidas. Efetivamente, a tática de enfrentamento por meio das ocupações de terra foi diminuída em nome das negociações através das políticas públicas. Ainda assim, manteve a produção de moradia como ação política a partir da centralidade na qualidade dos processos de trabalho, desenho e tecnologia.

No caso do Jardim Salete, portanto, a tradição da autogestão cristalizada na presença da Usina encontrava outra forma de fazer política, marcada pela instrumentalização do déficit habitacional por meio da gestão de demanda e domínio territorial - elemento típico das forças sociais que atuam na periferia, a exemplo das igrejas neopetencostais e o crime organizado ${ }^{13}$. Tal articulação entre mediação comercial, território

\footnotetext{
${ }^{12}$ A Usina - Centro de Trabalhos para o Ambiente Habitado é uma assessoria técnica a movimentos populares que é formada em 1990 no bojo da ascensão do modelo uruguaio de produção de habitação por autogestão em São Paulo. Maiores informações: http://www.usina-ctah.org.br/.

13 Vale a pena notar que o PCC é identificado na periferia como "Partido do Crime", ou simplesmente "O Partido", explicitando a semelhança formal entre determinado tipo de organização política (principalmente aquela ligada ao domínio heterônomo de demanda e de território) e o crime organizado.
}

Dialektiké, v. 1, 2016. p. 52-78 
e Estado constrói determinada capilaridade de relações de poder da organização popular com a institucionalidade que age no negativo do aparente embate político. É assim que se costuram relações com a Polícia Militar, com a Caixa Econômica Federal e com as três esferas de governo (judiciário, executivo e legislativo), numa dialética entre o enfrentamento e o acordo. O aclamado "poder popular" parece alicerçado na conquista material por meio desta forma de ação, e não da formação autônoma da base dentro dos processos de luta e construção do urbano. Desta maneira, o processo junto ao MTST significava, para a Usina, abrir mão da autogestão no projeto e na obra - que foi sempre pensada para ser feita por meio de uma construtora, por conta mesmo dos objetivos pragmáticos do movimento em relação à construção de unidades habitacionais.

Começa aqui uma dinâmica entre a assessoria e o movimento que vai durar 6 anos e que expressa o embate entre diferentes programas políticos para a ação no setor da moradia, exemplares para a reflexão crítica dos caminhos da esquerda durante o período do PT no governo federal. Veremos, pelas idas e vindas dos projetos arquitetônicos e urbanísticos e das relações entre as forças sociais envolvidas, como a construção final do Jardim Salete (ainda em processo) é a materialização idiossincrática e histórica de um momento político nacional, onde se encontram, de um lado, organizações populares, mercado e Estado de maneira consonante, porém instados a dar conta de um programa dissonante formado em outro tempo histórico, mas resistente. A posição do MTST, neste caso, é bastante dialética e demonstra a passagem estreita de ascensão de uma forma específica de transformação das forças populares no período.

A Usina fez, no primeiro semestre de 2009 , um projeto preliminar para o terreno que tinha como objetivo a qualidade urbana e arquitetônica. Seguindo um processo de pesquisa e aperfeiçoamento na prática de projetos em estrutura metálica para habitação popular, propôs um conjunto de prédios que resolvia a necessidade de adensamento sem elevadores. A partir da legislação de Bombeiros, o número máximo de andares de edificações sem elevador (térreo mais quatro) contabiliza apenas os andares de acesso aos apartamentos. Com o uso do duplex, conseguia-se um andar a mais, diminuindo também o custo com circulação comum nos edifícios (que fica pela metade e supera em economia o gasto com circulação interna nas unidades habitacionais). Urbanisticamente, a solução previa áreas verdes, institucionais (EMEI, EMEF e UBS) e de lazer, num desenho de núcleos que qualificava uma escala comunitária interna ao mesmo tempo em que dava vida à rua, com espaços fluidos de conexão urbana. Com esta proposta, o conjunto alcançava 920 UHs, respeitando toda a legislação com qualidade e economia projetual, fruto da experiência da assessoria técnica com produção habitacional com movimentos populares.

A utilização da estrutura metálica merece atenção particular. Ela permite o aproveitamento da topografia natural do terreno para diminuir os gastos com movimentação e contenção de terra, além de dar flexibilidade para o espaço interno do conjunto se abrir para a cidade, num desenho mais urbano do que ligado ao lote. No campo da arquitetura, ela permite a combinação da padronização de elementos fabricados industrialmente com a possibilidade de arranjos não padronizados no espaço, qualificando a edificação e sua adaptabilidade no terreno e no entorno. Internamente aos apartamentos, sua lógica estrutural permite flexibilidade dos ambientes, dando abertura para uma maior intervenção do usuário e adequação às diferentes necessidades dos núcleos familiares. No momento da obra, ela tem ganho de escala ao diminuir o tempo de consolidação estrutural 
do edifício, além de oferecer melhores condições de logística de canteiro (ao antecipar as circulações verticais), melhores condições de trabalho, um canteiro limpo e muito mais controlado no que concerne ao desperdício, ao tempo de obra e às normas de desempenho. É uma tecnologia adaptada à produção em massa, urbana, com qualidade. Pode-se considerar que seu emprego é um avanço das forças produtivas, porém subordinadas, no caso, ao processo de autogestão nas relações de produção.
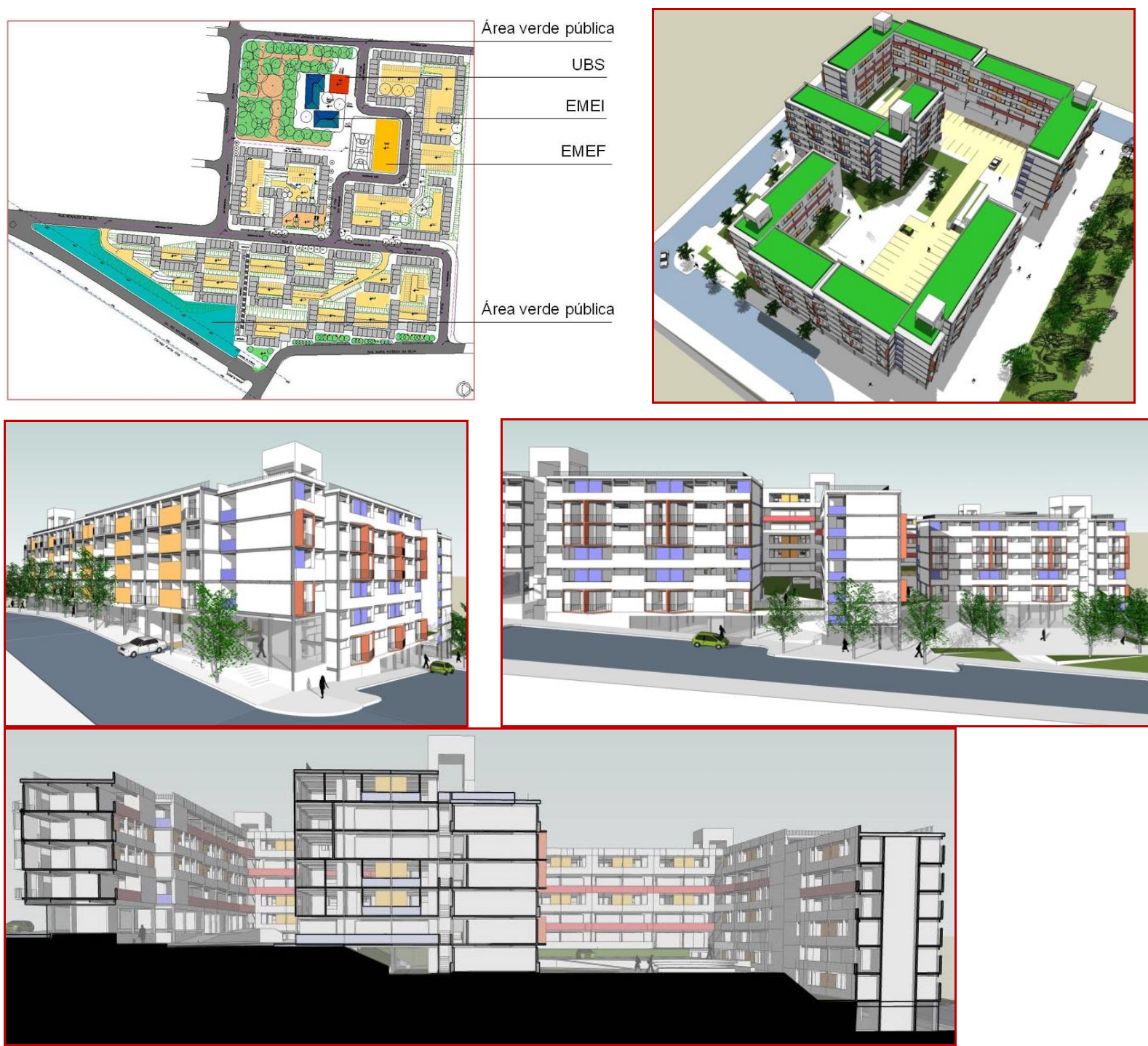

Figuras 1 a 5: Projeto original realizado pela Usina para o Jardim Salete, em 2009. Fonte: arquivo da Usina.

Para além dos ganhos no desenho e na obra, a estrutura metálica tem uma cadeia produtiva toda nacional (da extração à extrusão de perfis), e que tem sua maior parte exportada por falta de mercado interno, aquecimento do mercado chinês e câmbio favorável. As relações macroeconômicas são importantes neste caso, pois se trata de uma commodity que tem seu preço definido pelo mercado internacional, embora tenha produção 
e know-how nacionais ${ }^{14}$. Seu preço sendo definido pela flutuação externa faz com que sua aplicação para o interesse nacional seja instável e de difícil consolidação como tecnologia permanente na construção civil, principalmente na habitação popular. É reiterado, aqui, o papel brasileiro de exportador de produtos primários em detrimento do interesse nacional.

O projeto da Usina foi apresentado para a CDHU, responsável pela construção, depois de passar por algumas apresentações públicas massivas - numa ação mais de legitimação do projeto, como uma ação do movimento e não do Estado, do que de participação. A Companhia aguardou o lançamento do PMCMV, quando transferiu seu protagonismo para o governo federal, passando a ter um papel de aporte de recursos extras por meio da Casa Paulista para os empreendimentos do programa executados no estado. A CDHU desmonta seu aparato técnico ao longo dos últimos sete anos, deixando de ser produtora de unidades e grande banco de terras públicas (pelo seu papel central na desapropriação de terrenos para habitação popular). A partir de então nega qualquer ação de desapropriação, seja para construção seja para urbanização, pelo fato de que o programa federal inclui no seu financiamento a compra de terras no mercado.

O terreno foi comprado da CDHU no âmbito do PMCMV para o MTST através da modalidade Entidades (vinculada a recursos do FDS), com recursos adiantados pela Casa Paulista (agência vinculada à $\mathrm{CDHU}$ ). Resultou que o aporte desta agência para a fase de obra foi menor do que o padrão, por conta deste repasse para a compra da terra dela mesma. Neste acordo, também se pode ver o poder de negociação do movimento, dado que este procedimento foi negado pela Companhia em ocasiões posteriores.

Nesta conjuntura, o projeto da Usina foi mal recebido na CDHU, que colocou uma série de entraves que demonstravam, na verdade, sua normal aversão a projetos não padronizados e com excesso de elementos inovadores (teto verde, unidades duplex e de área superior ao mínimo exigido, estrutura metálica, equipamentos públicos, condomínios abertos e projeto de loteamento ao invés de uma série de desdobros). A disputa teve seu ápice quando a Companhia utilizou uma de suas terceirizadas para fazer um relatório que "demonstrava" tecnicamente que o projeto era inviável economicamente não por apresentar um orçamento excessivamente alto, mas por ter uma série de elementos de risco. Nada que não fosse esperado, dado que os empreendimentos dos movimentos de moradia sempre foram não padronizados e resultados de processos de luta, inclusive técnica, no interior dos órgãos públicos. Este sempre foi um dado inicial, considerando que a organização popular está em luta não apenas pela unidade habitacional mínima - dentro da lógica do Estado e do mercado -, mas por direito à cidade, o que significa, na prática, transformá-la e, portanto, produzi-la de maneira diferenciada ${ }^{15}$.

\footnotetext{
${ }^{14}$ Todos os empreendimentos da Usina em estrutura metálica foram produzidos e montados pela Usiminas. $\mathrm{O}$ último empreendimento, único com toda a estrutura metálica (Paulo Freire, em Cidade Tiradentes, São Paulo), foi possível pois o preço do minério de ferro, entre 2002 e 2003, estava em cerca de US\$ 13/Ton. Quando o Jardim Salete foi orçado (primeiro semestre de 2009), este valor era de US\$ 75/Ton, em alta, que chegou ao pico em fevereiro de 2011, a US\$ 187/Ton, depois decrescendo até chegar, hoje (maio 2016), no mesmo patamar do final de 2007 (em torno de US\$ 40/Ton). Fonte: http://www.indexmundi.com/pt/pre\%E7os-demercado/?mercadoria=min\%C3\%A9rio-de-ferro\&meses=180 acessado em 20 de maio de 2016.

15 Justamente entre o final de 2009 e o início de 2010, quando a CDHU está combatendo o projeto da Usina pelo excesso de inovação, lança junto ao IAB (Instituto de Arquitetos do Brasil) o concurso "Habitação para Todos: Concurso Nacional de Projeto de Arquitetura de Novas Tipologias para Habitação de Interesse Social
}

Dialektiké, v. 1, 2016. p. 52-78 
O MTST, no entanto, reafirma sua postura inicial, na qual a construção no Jardim Salete tinha significado estratégico na nacionalização do movimento como vitória material (para as bases) e como articulação interna ao Estado. Segundo ata de reunião da Usina: "[Arquiteto $\mathrm{X}$ ] conversou com o [Liderança $\mathrm{Y}$ ] que assumiu a importância de bancar o projeto por ser diferenciado e de que o movimento quer realizá-lo. Só que a preferência do movimento é a de concretizar (realizar conquistas), e se a briga for muito desigual há possibilidade de focar noutras coisas". A avaliação do movimento, ao final, foi de que não enfrentaria a $\mathrm{CDHU}$, aceitando o projeto que ela fizesse.

Neste momento, de um lado da mesa se posicionaram a equipe técnica da SEHAB de Taboão da Serra e a assessoria técnica e, de outro, os movimentos e a CDHU, que continuava a impor seu projeto com a promessa de que, por estar dentro dos 'moldes' da companhia, teria o processo de aprovação agilizado. Assim, os movimentos dispensaram a assessoria técnica da Usina CTAH, optando, naquele momento, por dar uma resposta mais rápida à população que, junto a eles, engrossava as ocupações, argumentando o fato de que eles tinham 'mais condição de pressionar a CDHU do que a Usina' (CAMARGO: 2016, 199).

\section{OUTRO PROJETO DE CIDADE: MAIS DO MESMO}

Quase dois anos depois, no final de 2011, o MTST retorna à Usina para apresentar o projeto concluído da CDHU. Dos princípios de qualidade originais, apenas ficava uma unidade habitacional maior do que a padrão, exigência do movimento por identificar de maneira bastante pragmática para a base e a opinião pública sua força política - pois esse elemento expressava cabalmente que o movimento enfrentava os interesses do mercado imobiliário. Trata-se de um fator qualitativo expresso pelo quantitativo, elemento midiático importante pois de fácil apreensão, além de mínimo na questão orçamentária ${ }^{16}$. Os edifícios tinham sérios problemas de insolação, além de apresentar desperdício de área de circulação comum. A movimentação de terra e contenções eram muito mais custosas, pois os edifícios estavam implantados em grandes patamares, para receber prédios de estrutura pouco flexível, acarretando em desequilíbrio de cortes e aterros e muros de arrimo muito altos.

Urbanisticamente a questão era ainda mais grave. O projeto original previa, para o empreendimento Chico Mendes, um loteamento que inseria grande espaço público na forma de uma nova via que articulava os equipamentos públicos e de lazer, criando centralidade e comunicação dos diversos condomínios numa escala maior do que a comum (interna às quadras) que integrava o conjunto à cidade. No projeto da CDHU, não havia

Sustentáveis", colocando o terreno do Jardim Salete como base para as propostas, demonstrando seu jogo político entre o real e o aparente.

16 Uma unidade habitacional maior, porém com a mesma quantidade de cômodos, tem apenas (poucos) metros de piso, parede e cobertura a mais, porém continua tendo a mesma quantidade de janelas, pontos hidráulicos e elétricos, além do mesmo trabalho técnico e produtivo. 0 crescimento da unidade, portanto, não significa um crescimento proporcional de custo, principalmente quando se trata de uma produção em escala, como o caso aqui apresentado.

Dialektiké, v. 1, 2016. p. 52-78 
previsão de loteamento, mas do desdobro da área do Conjunto Chico Mendes em quatro condomínios fechados. As áreas verdes eram exíguas e isoladas e não havia previsão dos equipamentos públicos - apenas a indicação de uma área institucional bem pequena, separada dos condomínios. Tudo isso sem respeitar a legislação municipal, pois o empreendimento não alcançava a densidade exigida, chegando em 808 UHs, número inferior ao projeto da Usina.
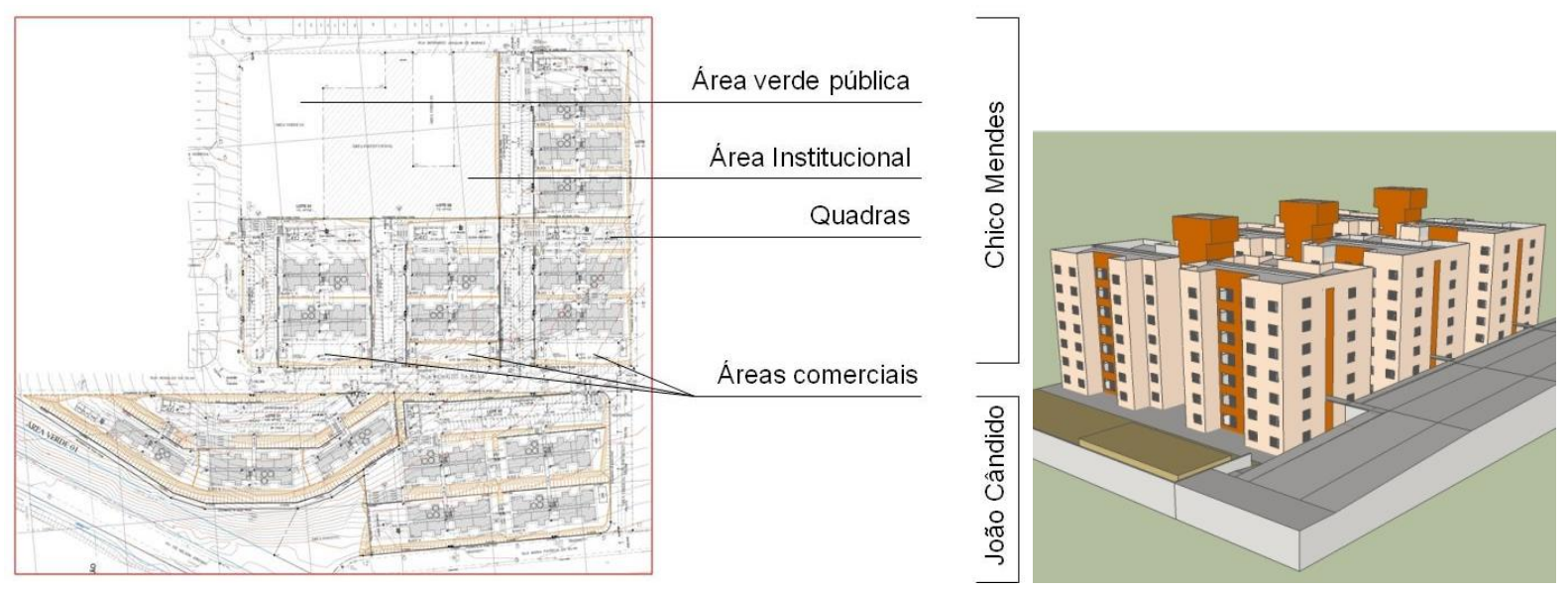

Figuras 6 e 7: Projeto realizado pela CDHU para o Jardim Salete, entregue em 2011. Fonte: arquivo da Usina.

O MTST então pressiona a construtora a contratar a Usina para fazer uma revisão no projeto. A primeira apenas aceita na medida em que é convencida de que terá economias, principalmente na movimentação de terra. Note-se que um conhecimento adquirido junto aos movimentos populares por parte da assessoria, que sempre trabalhou na diminuição dos custos com um desenho racional e adaptado a cada situação particular, ligado às necessidades do canteiro e dos trabalhadores e não aos interesses de ganhos extras das construtoras, é agora apropriado pelo capital pouco adaptado a este tipo de obra e de financiamento.

Esta apropriação de saberes é induzida, no caso do PMCMV, na medida em que o sistema de remuneração das construtoras se dá via repasse ${ }^{17}$, e não via licitação. $O$ repasse é um mecanismo que, ao definir artificialmente o preço de mercado, transforma a dinâmica da concorrência, incentivando o avanço da mais-valia relativa. Sem possibilidade de aditamentos ou cartelização em licitações, os ganhos precisam vir de uma transformação interna nas relações de produção e no necessário avanço das forças produtivas, historicamente barrado no Brasil por conta da sua posição dependente no mercado mundial ${ }^{18}$.

\footnotetext{
${ }^{17}$ O repasse é uma forma de investimento estatal na qual há um preço pré-fixado para a mercadoria ou serviço contratado, sem possibilidade de aditamento, mas sem risco para o capital privado, que tem o retorno do seu investimento assegurado na medida em que não há necessidade da venda da unidade habitacional.

18 Segundo Ruy Mauro Marini, a relação de dependência dos países latino-americanos baseia-se na sua condição de produtores de mercadorias em setores de baixa composição orgânica do capital, que transferem valor para setores de maior composição orgânica predominantemente nos países centrais, por meio do
}

Dialektiké, v. 1, 2016. p. 52-78 
Há uma mudança interna no setor da construção civil após 2005, que explica esta guinada: sua articulação com o setor financeiro. Neste ano, o Sistema Financeiro Imobiliário (SFI) passa a funcionar efetivamente, depois de sua regulamentação em 1997, por conta de melhorias institucionais promovidas pelo governo Lula, criando instrumentos de ligação entre este mercado e o de capitais $^{19}$ por meio da possibilidade de securitização da propriedade imobiliária. Além disso, as empresas do setor abrem capital na bolsa, fazendo sua produção responder a necessidades de rendimento de outro tipo de capital. Esta conjuntura introduz outras necessidades na cadeia produtiva, relacionadas, principalmente, a um aumento absoluto das mercadorias produzidas e outro relativo, com incremento da produtividade e da diminuição do tempo de rotação do capital ${ }^{20}$. No entanto, o papel da burguesia interna no pacto de dependência a impede, historicamente, de investir no desenvolvimento das forças produtivas.

Enquanto houver a possibilidade de venda de um produto produzido com meios arcaicos baseados na força animal, o que significa, enquanto não for imposto pelas regras da concorrência a redução do valor da unidade produzida, não haverá progresso. $\mathrm{O}$ capital faz avançar as forças produtivas mas 'na marra' e a contragosto. Por que se arriscariam os capitalistas se, com o 'know-how' adquirido, hábitos depositados, equipamento amortizado, administração e operários com comportamento conhecido e controlado produzem e vendem? Para que tentar e ousar temerariamente? (FERRO: 2006 [1972], 85).

A necessidade de alterar as relações internas de produção da construção civil é uma condicionante nova, imposta por fatores externos (o que reitera a função dependente), que

mecanismo de equalização pelo lucro médio. Como forma de compensação interna desta remessa de valor ao exterior, as relações de produção nacionais são baseadas na superexploração da força de trabalho (ver nota 20) (MARINI: 2005 [1973]). Sérgio Ferro faz leitura muito próxima quando analisa a construção civil no Brasil no mesmo período de Marini, no texto "A produção da casa no Brasil”, publicado originalmente em 1972, com o título "A casa popular". Para o autor, a construção civil no país, baseada em relações de produção manufatureiras, não tinha condições de se industrializar por conta da sua funcionalidade sistêmica: "Em tese, são áreas de produção arcaicas, como a construção civil, que garantem uma taxa de lucro alta, num país subdesenvolvido, já que utilizam um capital constante relativamente menor que o capital constante industrial" (FERRO: 2006 [1972], 99). Com um salário rebaixado por conta da pressão do exército industrial de reserva, o custo da mão de obra seria baixíssimo (conceito próximo ao de superexploração), incentivando a permanência de setores "atrasados", porém funcionais.

${ }^{19}$ Certificados de Recebíveis Imobiliários (CRI), Cédulas de Crédito Imobiliário (CCI) e as Letras de Crédito Imobiliário (LCl).

20 Sérgio Ferro fala especificamente que estes dois fatores são característicos da construção civil em país dependente, que a impedem de ser tão funcional para o sistema (no início da década de 1970): “Há, entretanto, na construção civil uma característica que diminui ligeiramente o efeito compensador para o sistema, no seu conjunto, de sua superior taxa de lucro: o tempo de giro do capital. Esquematicamente, capitais produzem lucros reais (não os aparentes) maiores se seu tempo de giro for menor, supondo-se composições orgânicas semelhantes. Entretanto, devemos considerar o seguinte: em primeiro lugar, poucos capitais empregados em ouros setores, principalmente industriais, têm composição orgânica tão baixa. Somente outros ramos atrasados seriam comparáveis. Mas, entre estes ramos atrasados, poucos têm a característica específica da construção civil: a quase ausência de capital fixo, investido em bens pesados de produção" (FERRO: 2006 [1972], 100).

Dialektiké, v. 1, 2016. p. 52-78 
necessita, agora, de atualização da "plataforma de valorização financeira internacional" para continuar o mesmo mecanismo de transferência de valor. Assim, é necessária uma intervenção de uma instituição de classe para fazer esta atualização "na marra", fazendo com que o capitalista individual mude seu comportamento, contra seus interesses imediatos. Daí entra o papel do lulismo e seu Estado, por meio aqui do PMCMV.

Seguramente, a forma de produção arcaica será contestada por capitalistas cuja fome próxima de mais-valia afasta a cautela a longo termo. Os prognósticos, no caso, são bastante difíceis. O que é seguro é que haverá atrito entre os capitalistas isolados e seus representantes no poder, que têm os olhos postos na classe e menos no seu componente particular. Mas não ultrapassará, seguramente, a região das disputas cordiais. Afinal, eles se entendem (FERRO: 2006 [1972], 101).

Nada mais atual para explicar o que André Singer recentemente (SINGER: 2015) questionou para a reflexão político-acadêmica: por qual razão, em determinado momento, o capital produtivo rompe com o PT, que se aliava a ele? Primeiro: como visto, tal capital se desenvolve no último período como forma de dar resposta a um novo momento da economia mundial, onde há predominância do capital financeiro. Segundo: a necessidade deste capital é apenas a de atualizar a plataforma de valorização representada pelo Brasil, e para isso serve-se do Estado como gerenciador do interesse de classe que enfrenta o do capitalista individual, do seu ponto de vista imediato. Faz isso através de mecanismos de indução, como o repasse e a obrigatoriedade de certificação. Neste sentido, há avanço das forças produtivas por um período determinado pelos interesses da finança, no qual os capitalistas individuais são coagidos a fazer transformações internas na produção por meio do Estado como representante de classe (expresso no pacto CUT/FIESP a que se refere Singer). Consolidado este período de atualização, muda a qualidade da necessidade do pacto de classes e os capitalistas individuais novamente retomam o poder do Estado no seu habitual gerenciamento dos nossos elementos arcaicos ou subsumidos "na medida certa", para que fluidifique o canal de transferência de valor.

Nesta medida, a construtora do Jardim Salete aceita a intervenção de certa racionalidade de projeto construída pelo saber popular vinculado ao conhecimento técnico engajado da Usina, pois é induzida a isso. Seu modus operandi habitual não dá conta do mecanismo do repasse, que exige racionalidade - uma característica que foi necessária para o movimento popular no período anterior e que agora se volta contra ele, na forma de um avanço da subsunção real do trabalho ao capital na aplicação de certa tecnologia, controle de produção e produtividade. Se a racionalidade do movimento popular no processo produtivo estava a favor de um desenho de cidade alternativo, ela agora é usada para um desenho urbano que radicaliza a forma abstrata da razão do capital.

Nesta situação extremamente contraditória é possível entrever e pensar na dialética própria ao lulismo, que trabalha na atualização desta plataforma de valorização refuncionalizando o papel dependente do país. Usa para isso a expropriação de saberes de 
projeto, a desqualificação da mão de obra (por meio da superexploração ${ }^{21}$ e da negação dos ofícios operários), o aumento do controle do canteiro (impossibilitando o controle do trabalho pelo trabalhador) e a potencialização da associação da extração de mais-valia absoluta e relativa no aumento desmesurado da escala da produção habitacional e da mudança de sua composição técnica. Tudo isso com apoio das organizações populares, que veem o avanço das forças produtivas do capital como um meio de expansão política associando negociação com o Estado, espetacularização e acordo com o capital produtivo e o fundiário (incorporando terras antes improdutivas para o capital imobiliário).

Retoma-se, de maneira mais complexa, o antigo pacto dos trabalhadores com a burguesia nacional, num requentado que novamente se nega a encarar as relações de produção, com as organizações dos trabalhadores dando impulso ao novo período de exploração. Mais do mesmo, com o apoio significativamente novo das mídias sociais, que tendem a construir poder por meio do espetáculo e aumentar o valor do culto à personalidade, no caso, de lideranças que se apresentam como portadoras da fala dos trabalhadores. Não deveria, neste aspecto, ser motivo de espanto nem as alianças do PT com a burguesia, nem do MTST com o PMCMV - fato este que ficou cabalmente provado na verdadeira cruzada do movimento pela defesa do programa na sua terceira fase, com direito a lugar na mesa de lançamento.

O lulismo, nesta ótica, pode ser entendido como uma gestão da dialética própria a um país dependente, na qual os déficits sociais são funcionalizados como meios de expansão do capital ${ }^{22}$ e, no seu negativo, de organizações populares que cumprem função de gestão dos conflitos de classe em troca de sua extensão de domínio territorial e de demanda, entendidos como conquista popular. Ganhos para todos, na medida em que trabalham numa mesma forma, pelo positivo ou pelo seu negativo: o desenvolvimento das forças produtivas do capital e, no seu negativo, do trabalhador como elemento do mesmo, e não como força contrária.

\section{UMA SÍNTESE DIALÉTICA OU UM ORNITORRINCO?}

A Usina é então autorizada a fazer mudanças pontuais nas edificações, que tragam economia e não aumento de qualidade de vida, e melhora apenas a distribuição dos apartamentos para diminuir área de circulação comum - em contradição com sua própria tradição projetual, que entendia esta circulação como uma escala importante do convívio comunitário e que deveria ser aumentada, como uma sala de estar comum. No conjunto João Cândido, rotaciona os edifícios para melhorar a insolação, inclui uma área institucional e aumenta a quantidade de platôs melhorando a movimentação de terra e o impacto de grandes taludes no desenho urbano e sua fluidez. Urbanisticamente, no entanto, tenta trazer de volta elementos que propôs no projeto original para o conjunto Chico Mendes.

\footnotetext{
${ }^{21}$ Segundo Marini, a "superexploração" é uma característica que especifica o capitalismo dependente latinoamericano, sendo definida pela remuneração da força de trabalho abaixo de seu valor. Ou seja, "são negadas ao trabalhador as condições necessárias para repor o desgaste de sua força de trabalho" (MARINI: 2005 [1973]).

22 David Harvey trabalha com esta hipótese no conceito de "acumulação por espoliação", baseado em Rosa Luxemburgo (HARVEY: 2004).
}

Dialektiké, v. 1, 2016. p. 52-78 


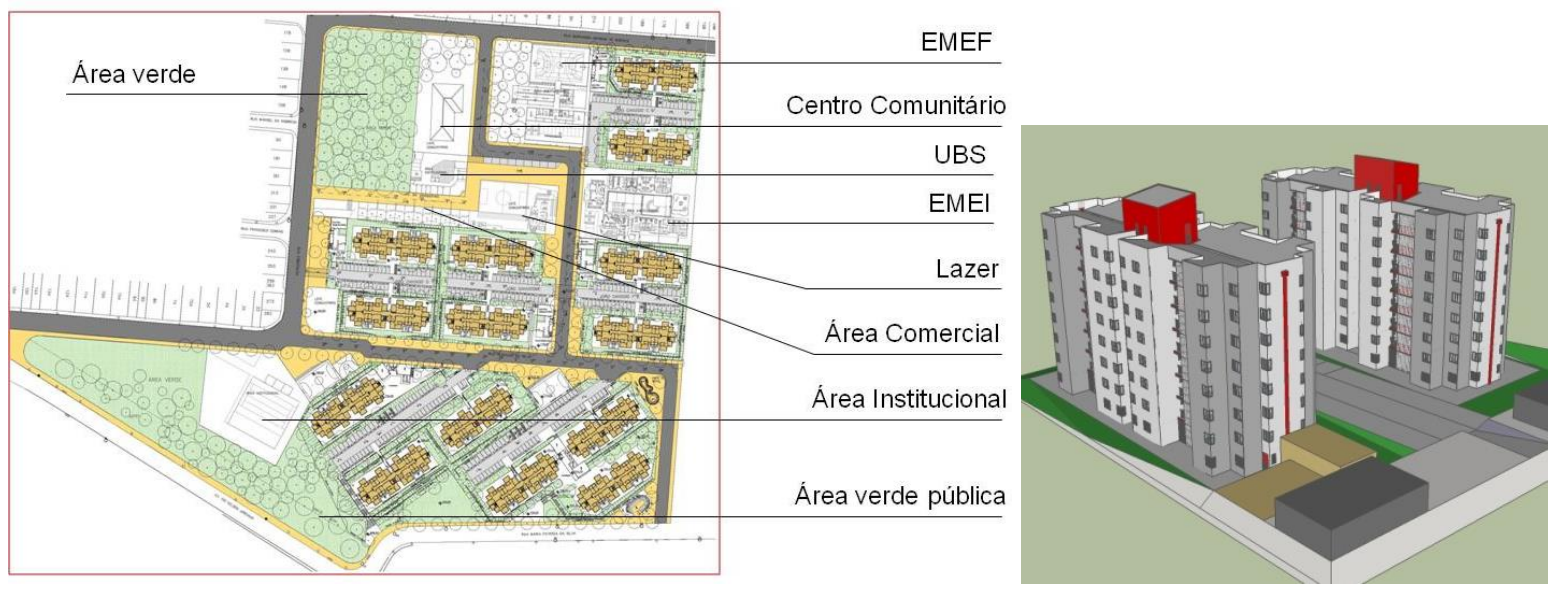

Figuras 8 e 9: Revisão do projeto da CDHU, realizada pela Usina em 2012. Fonte: arquivo da Usina.

O loteamento é retomado, com grande doação de áreas públicas - uma rua, área verde e duas grandes áreas institucionais (EMEI e EMEF) -, integrando os condomínios através da sua articulação num grande espaço de uso público e comunitário, com uso misto (lazer, comércio, equipamentos públicos e comunitários). Um desenho efetivamente de uma parte de cidade, uma relação entre espaço público e privado de acordo com uma perspectiva do urbano como potência integradora de seus habitantes, no caso, uma intervenção direta de uma organização política no tecido urbano que daria novos caminhos depois da sua ocupação. Isso pôde ser efetivado pela inserção do uso do elevador nas tipologias já definidas pela construtora, aumentando os edifícios para oito andares e abrindo espaço urbano. Os ganhos advindos do aumento de unidades (agora 896) convenceu a construtora a adotar esta medida.

O uso de elevadores sempre foi inviável em habitação popular pelo seu alto custo (direto e indireto, pois a estrutura do edifício é diferente para aumentar sua verticalidade). É questionado pela área social pelas suas dificuldades de custo e logística de manutenção por uma população de risco; não desejado pelas lideranças populares pela dificuldade de organização de uma densidade grande de famílias; e é polêmico entre os arquitetos e urbanistas pois se, de um lado, aumenta a área urbana livre e adensa a cidade racionalizando custos de urbanização, por outro, dificulta o convívio social transformando a escala humana de vida na abstração do homem modernista universal, confinado à "máquina de morar" corbuseana. Estes argumentos, no entanto, têm sido minimizados pelos movimentos de moradia (inclusive os tradicionais) em nome da viabilização dos empreendimentos, que precisam ser verticalizados por conta do adensamento necessário requerido pelo custo da terra. Como o PMCMV paga a terra de acordo com um percentual do valor de repasse (sempre fixo), seu custo é sempre fixado pela sua capacidade máxima de construção (metros quadrados) de acordo com a legislação municipal que, no caso, acaba sendo expressa pelo número de unidades. A lógica é de que elas devem ser muitas, por isso pequenas, para dar conta do potencial construtivo com maiores ganhos, pois o pagamento não é por metragem quadrada (na lógica da licitação), mas por unidade habitacional (na lógica do repasse). Neste sistema, o movimento popular é levado a minimizar questões

Dialektiké, v. 1, 2016. p. 52-78 
sociais, políticas e urbanas relevantes (e que sempre estiveram na sua pauta de reivindicações), em nome de uma lógica externa à sua e que deveria, justamente, ser combatida por representar os interesses quantitativos do capital, e não qualitativos dos trabalhadores.

Assim, percebe-se que o projeto revisado pela Usina não era, de longe, seu projeto original - que inclusive comportava mais unidades. E as contradições expressas neste último são um bom exemplo da dialética própria ao lulismo. Principalmente pelo fato de que as articulações entre os interesses do capital e dos trabalhadores se coadunam de uma forma específica, dando potencialidade à ação de ambos - na medida em que seus objetivos se encontram na mesma forma política ligada à expansão do capital. Nesta esteira, surgem edifícios de qualidade arquitetônica truncada entre aumento do espaço privado ${ }^{23}$, diminuição do comum, verticalização exigida pelo interesse do capital fundiário e processo construtivo que, ao mesmo tempo, avança na subsunção real do trabalho ao capital e na dependência do país e, por outro lado, responde à necessidade de conquista rápida de muitas unidades pela organização popular. No campo do urbano, trata-se da disputa de um projeto de cidade mais ou menos privatizado, mais ou menos direcionado ao usufruto e trocas entre as pessoas na riqueza das diversas relações urbanas e escalas de convivência, ou como resposta à racionalidade quantitativa do capital.

A tecnologia construtiva adotada pela construtora é baseada no uso do Concreto Auto Adensável (CAA), que preenche fôrmas pré-fabricadas onde já estão embutidas as redes (elétrica e hidráulica). $O$ trabalho de canteiro envolve a montagem dessas fôrmas e o despejo do concreto, que não precisa de vibração para preenchê-las. Neste procedimento, são retirados do canteiro alguns dos principais oficiais (trabalhadores mais qualificados, que se especializam em determinado ofício ligado à produção manufatureira típica da construção civil brasileira): pedreiros (e "bloqueiros", especialistas em alvenaria estrutural), marceneiros, carpinteiros, além de diminuir o controle operário sobre outros serviços, como as redes e armações, e retirar da obra os imensos contingentes de serventes. Os operários contratados são treinados durante uma semana para ter conhecimentos específicos e pouco replicáveis para fazer procedimentos padrão, rebaixando, na média, o custo da mão de obra.

Além disso, é uma tecnologia importada, largamente utilizada justamente nos países de inserção dependente no mercado mundial e que, portanto, mantiveram a construção civil ligada ao setor habitacional em níveis de subordinação formal do trabalho ao capital, com baixa composição orgânica, até pouco tempo atrás. Por isso, é uma tecnologia bem adaptada a um tipo específico de ciclo de reprodução do capital, no qual se combinam a superexploração com uma lógica produtiva baseada na padronização máxima

\footnotetext{
${ }^{23}$ As unidades habitacionais maiores do que o padrão do PMCMV, incluindo variação tipológica de dois e três dormitórios, é o elemento central da propaganda política do MTST, como indicador unívoco de qualidade e enfrentamento ao capital, o que é bastante contestável do ponto de vista urbanístico. No entanto, cabe refletir sobre o significado desta defesa tendo em vista o sujeito político forjado como consumidor pelo lulismo e base do MTST: "conquista", para ele, tem a ver com os símbolos de ascendência individuais e materiais, identificados com a forma mercadoria. Qualidade, como fator de enfrentamento decisivo à lógica do capital, só pode ser entendida como quantidade: metros quadrados individuais a mais. Não é desprovido de coerência o fato de que, depois de ocupadas as unidades, as famílias do MTST contrataram uma empresa para fazer reformas individualizadas nos apartamentos, como símbolo de status, incluindo uma sauna particular em uma das unidades (Cf. CAMARGO: 2016).
}

Dialektiké, v. 1, 2016. p. 52-78 
que, no limite, dispensa o momento de projeto, para alcançar ganhos de escala ${ }^{24}$ (uma particular articulação entre mais-valia absoluta e relativa). Isso é conseguido sem um parque industrial instalado (como o aço) e sem custos de projeto vultuosos (desenho e engenharia), pois sua aplicação é simplificada (diminuindo e precarizando mão de obra) e toda a pesquisa de materiais e montagem é feita no exterior.

A construtora do Jardim Salete adotou esta tecnologia, que ganhou escala no Brasil por conta das necessidades de produção impostas pelo PMCMV. Aplicou-a, diferentemente da maioria dos casos, em edifícios em altura, numa clara experimentação da tecnologia possibilitada e induzida pelo Estado por meio do programa. José Baravelli descreveu este fenômeno a partir da investigação dos incentivos possíveis para o investimento na Faixa 1 do PMCMV pelas construtoras, dado seu baixo retorno financeiro:

\begin{abstract}
A tendência de concentração de renda no programa MCMV, por outro lado, torna o 'laboratório da baixa renda' ainda mais atraente para as grandes empresas construtoras, que já possuíam certificação de qualidade quando do lançamento do programa federal. Para estas, a tecnologia a experimentar nas seguras condições dos empreendimentos da Faixa 1 amplia os aspectos organizacionais no sentido da gestão de novas tecnologias construtivas. A tecnologia do concreto auto-adensável (...) passou a ser empregada nos empreendimentos de baixa renda em associação com fôrmas de parede e laje, de produção complexa e de alto custo. No entanto, ao final de um empreendimento da Faixa 1 do programa MCMV, o custo destas fôrmas não só está amortizado como também a tecnologia está testada, medida e incorporada aos demais processos construtivos da empresa construtora (BARAVELLI: 2014, 184).
\end{abstract}

Não é de se espantar, deste ponto de vista, que dada a consolidação da fase experimental e incremento da subsunção do setor ao capital, a Faixa 1 do PMCMV seja agora desnecessária, e caia junto ao governo que a criou. Atualizada a plataforma de valorização, ação que necessita da conciliação de classes do lulismo, sua manutenção retorna às mãos de uma burguesia que não necessita mais desta aliança.

\title{
7 CAPITAL E ORGANIZAÇÃO POPULAR SE ENTENDEM
}

A Usina permaneceu na obra do Conjunto João Cândido como fiscal contratada pelo MTST, pois a modalidade Entidades / Empreitada Global do PMCMV tem uma articulação idiossincrática de agentes. Embora o contrato se dê com a Entidade e a construtora seja

24 Os comentários de técnicos em diversas reportagens de revistas especializadas sempre justificam e defendem o uso do CAA com base no binômio produtividade e redução da mão de obra - fatores que compensariam o investimento inicial nas fôrmas e o custo mais alto do material, em comparação ao concreto comum. É uma tecnologia, portanto, que só faz sentido para países em processo de aumento do valor da mão de obra (pelo aumento dos níveis de consumo) e de seu preço (pelo aumento da concorrência promovido pelo pleno emprego), além de necessitar de escala produtiva. Um casamento perfeito com o Brasil lulista e um de seus braços, o PMCMV.

Dialektiké, v. 1, 2016. p. 52-78 
contratada dela, qualquer problema com a obra é de responsabilidade da Entidade, que por sua vez não tem acesso ao fluxo de caixa da construtora e não tem como saber quais as origens de qualquer desequilíbrio. A Caixa Econômica Federal exigia o acompanhamento técnico da Entidade e o MTST novamente procurou a Usina - mais como terceirizada do que como aliada política, já que negou a proposta da assessoria de manter as famílias mobilizadas em torno do acompanhamento de obra. Não era interesse para o movimento formar autonomia e poder descentralizado, dinâmica incentivada pela assessoria e que pôde, inclusive, ser identificada nas lideranças da pós-ocupação do conjunto, que se formaram justamente dentro da obra, porém como contratadas da empreiteira.

Sem ter muitas contribuições a dar na avaliação do desempenho da tecnologia altamente fechada nos seus processos devido ao controle centralizado e independente do canteiro - a Usina focou sua atenção na execução do projeto. Havia problemas crônicos de comunicação com a construtora, pouco afeita a este tipo de fiscalização. Depois de uma série de desencontros, a Usina pôde aferir com precisão que o que estava sendo realizado em obra era diferente do projeto realizado e aprovado na Prefeitura, sem conhecimento do movimento. Esta primeira divergência se limitava à rotação de dois edifícios do conjunto João Cândido para adequação a um patamar maior do que o projetado, aumentando a movimentação de terra e piorando a relação dos edifícios com as duas ruas adjacentes. A Usina então requer da construtora os projetos do Conjunto Chico Mendes, para aferir suas eventuais mudanças.

Projeto Aprovado
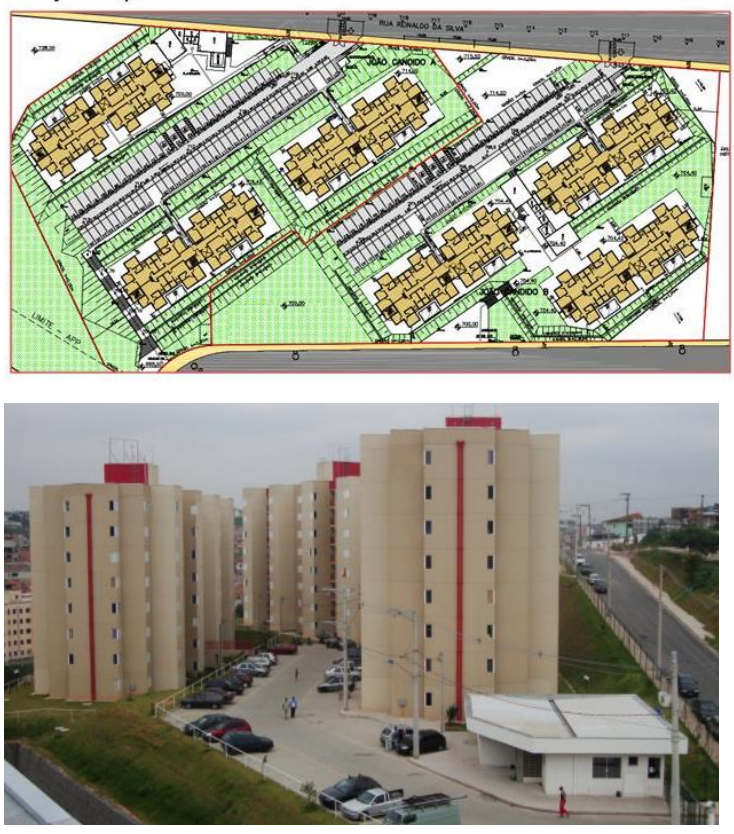

Projeto Executado
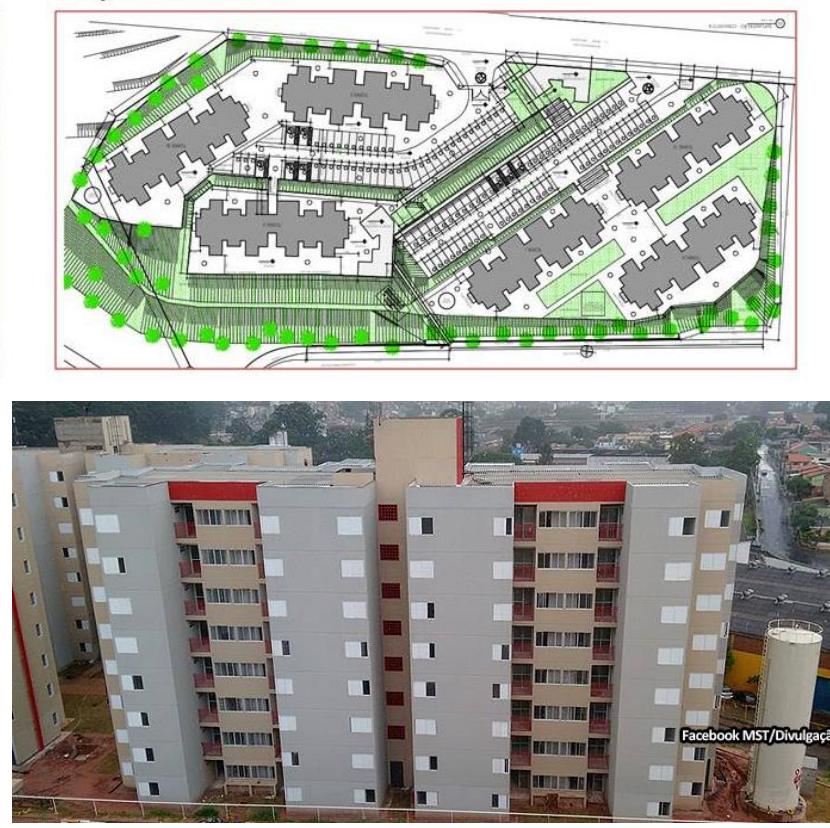

Figuras 10 a 13: Comparação do projeto aprovado e do realizado, com fotos do conjunto entregue. Fonte: arquivo da Usina e divulgação.

Efetivamente, a construtora havia mudado novamente o projeto, mesmo já estando aprovado nos órgãos públicos. Insistia no retorno ao desdobro, jogando as entradas dos condomínios para as ruas existentes, eliminando a centralidade pública do projeto revisado

Dialektiké, v. 1, 2016. p. 52-78 
pela Usina e aumentando o custo de manutenção condominial para as famílias. Para tanto, precisou deslocar uma das escolas para o perímetro da gleba, juntando dois condomínios em um só, para terem acesso único pela rua existente. A segunda escola tinha sido substituída por mais duas torres de habitação (mais $128 \mathrm{UHs}$ ) - decisão esta que o MTST aprovou em assembleia, justificada pelo aumento da demanda atendida (centro da sua ação política) com a contrapartida do governo estadual que se comprometia a construir uma escola no entorno do empreendimento. No entanto, o movimento não tinha tido acesso ao desenho final, que caracterizava esta mudança em termos de implantação. Uma das torres novas, inclusive, se posicionava a apenas 3 metros do casarão histórico utilizado então como sede do movimento e retirava área verde - fatos que não os agradaram.

Projeto Aprovado

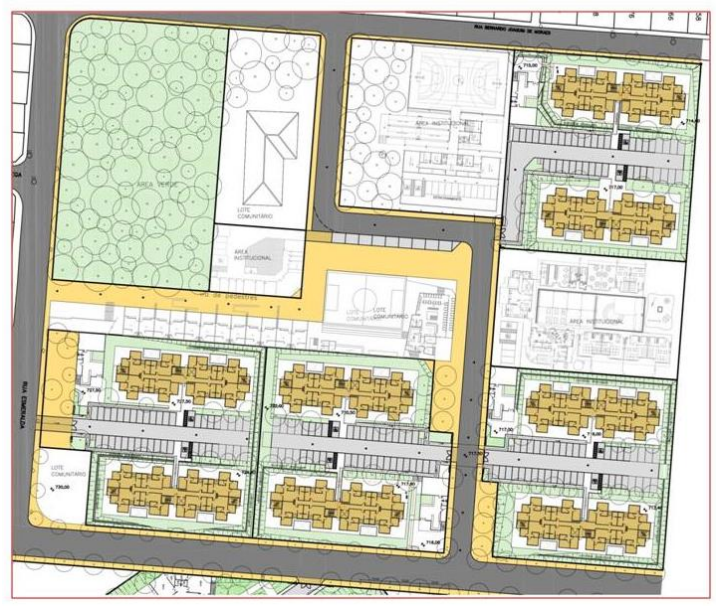

Projeto Revisado pela construtora

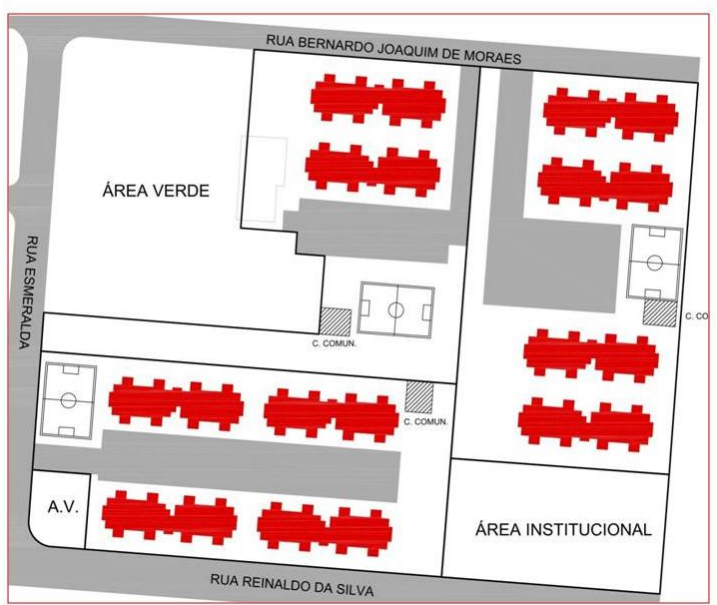

Figuras 14 e 15: Comparação entre o projeto aprovado e a revisão da construtora em 2014. Fonte: arquivo da Usina.

Note-se que a construtora utilizava o precedente aberto pela Usina de verticalização pelo uso dos elevadores e agora o associava ao seu projeto inicial de desdobro, potencializando os dois ganhos. Mais uma vez a contradição da ação da Usina se mostra patente, na medida em que suas proposições de projeto que dão abertura para a maior produtividade do capital são apropriadas e desviadas ao terem retiradas suas contrapartidas (no caso, mais espaço público alcançado pela verticalização). É deste ponto de vista que a Usina tomou a decisão de, por conta própria, mostrar que era possível o aumento de demanda requerido tanto pela construtora quanto pelo movimento, porém retomando a loteamento e a escola. É mais um capítulo da novela, no qual entram em confronto novamente interesses e formas diferentes de encarar a ação política no urbano que, no entanto, precisam ter solução material única.

\section{O TRUNCAMENTO DA FORMA URBANA}

Com a possibilidade demonstrada pela Usina de manter o aumento da demanda com o retorno da qualidade urbana proporcionada pelo loteamento, o MTST pressiona a

Dialektiké, v. 1, 2016. p. 52-78 
construtora a novamente contratá-la para revisar o projeto do Conjunto Chico Mendes. O resultado final - que no momento está aprovado, mas as obras ainda não iniciadas - é a forma própria de um programa urbano truncado, expressão da especificidade lulista. Não é um projeto nem da Usina, nem da CDHU, mas do MTST e seu hibridismo funcional. Ali se encontram sintetizados, por um lado, edifícios que são resultado de uma racionalidade própria ao capital no seu desenho e na sua produção, mas, ao mesmo tempo, carregando a marca das unidades maiores do que o usual; do outro, um desenho urbano que transita de maneira contraditória entre o modelo padrão do condomínio pragmático da CDHU (sem criação de escalas intermediárias e espaços comuns qualificados) e a inserção articulada de equipamentos e espaço público. É um desenho contraditório e tenso, expressando o convívio pouco tranquilo de programas urbanos diversos, que pendulam entre a massificação abstrata e a qualidade da articulação urbana.

O Jardim Salete acaba se tornando, por tudo isso, uma experiência fundamental de reflexão, pelo seu grau de contradição mediado pela forma urbana. Cabe lembrar que o ano de 2013, quando as obras dos condomínios do Conjunto João Cândido foram iniciadas, marcou uma mudança radical no espectro político do país com as Jornadas de Junho, o que foi identificado, simbolicamente, como o fim do lulismo e sua marcha lenta de conciliação de classes. Há, efetivamente, elementos importantes para esta conclusão que, no entanto, parece simplória do ponto de vista dialético. Talvez, melhor do que identificar um "fim", seria mais proveitoso identificar a movimentação histórica de seus elementos que, afinal, são rearticulações de uma dinâmica própria e conhecida do país.
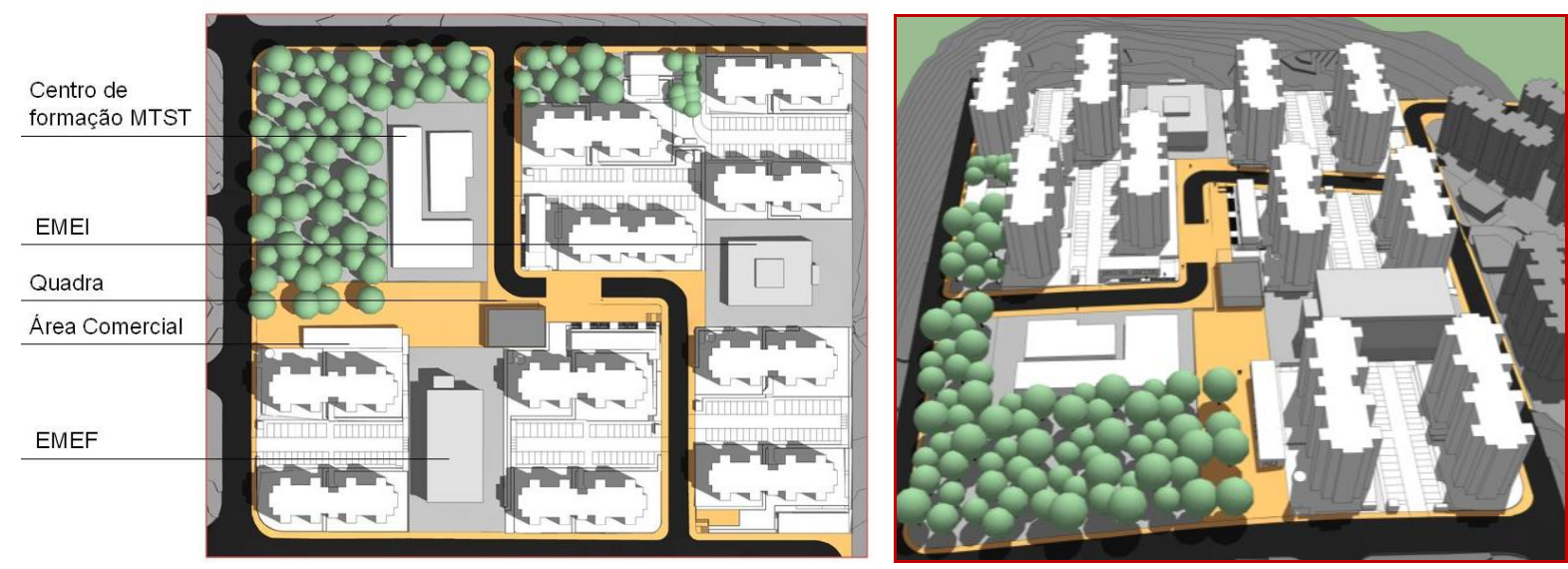

Figuras 16 e 17: Revisão final da Usina, em 2014/2015. Fonte: arquivo da Usina.

O ano de 2013 poderia ser lido, a partir deste pressuposto, como uma inflexão importante no campo das lutas urbanas, na qual se encontra o ápice e o declínio de uma forma política baseada na autonomia do sujeito, representada pelo Movimento Passe Livre (MPL), e a ascensão de outra, baseada no centralismo democrático e na intervenção urbana como domínio de território e de demanda, representada pelo MTST - forma esta que foi originada no seio do lulismo e que, portanto, faz a movimentação histórica de seus elementos para uma nova conjuntura, marcada pela radicalização dos conflitos de classe. 0 
MTST ascende, justamente, nestas condições, na medida em que carrega consigo um poder popular bastante específico: a movimentação de massas originadas por meio de uma articulação política pelo alto, forjadas através do modelo do sujeito consumidor, construído e mantido artificialmente por um Estado capilarizado em lideranças populares personalistas.

Esta confluência retoma, não por acaso, a discussão política da esquerda no momento do golpe de 1964. Naquele momento, o PCB (Partido Comunista Brasileiro) representava o campo dominante, com a seguinte tese: a necessidade de aliança dos trabalhadores com o capital produtivo nacional, em nome do desenvolvimento das forças produtivas que elevariam o patamar de organização da classe trabalhadora rumo à revolução. O golpe militar deixou claro o fracasso dessa estratégia. De outro lado, dissidentes, ligados à luta armada, chamavam a atenção para o fato de que o capitalismo não se desenvolvia da mesma maneira em todo o mundo, que a América Latina, em particular, tinha função dependente e que sua burguesia interna cumpria um papel político importante para a manutenção deste lugar econômico. Estes dissidentes ${ }^{25}$ deram luz ao mundo escuro e secreto das relações de produção e sua especificidade na América Latina dependente, apoiados numa leitura autônoma de Marx.

Vale pensar, em comparação, na estratégia política do MTST de aliança com o capital produtivo na construção civil por meio do PMCMV-Entidades, na modalidade da Empreitada Global. Nesta aliança, a estratégia política de construção do "poder popular" passa pelo mesmo interesse do capital no desenvolvimento das forças produtivas: produtividade e massificação, apoiados no aparato estatal e na ampliação da exploração. Desta maneira, negligencia a atuação política junto às relações de produção e à formação da base, o que passaria pela autogestão do canteiro e do desenho, na perspectiva de formulação de outro programa para as cidades, que envolve uma forma urbana de resistência e dissensual.

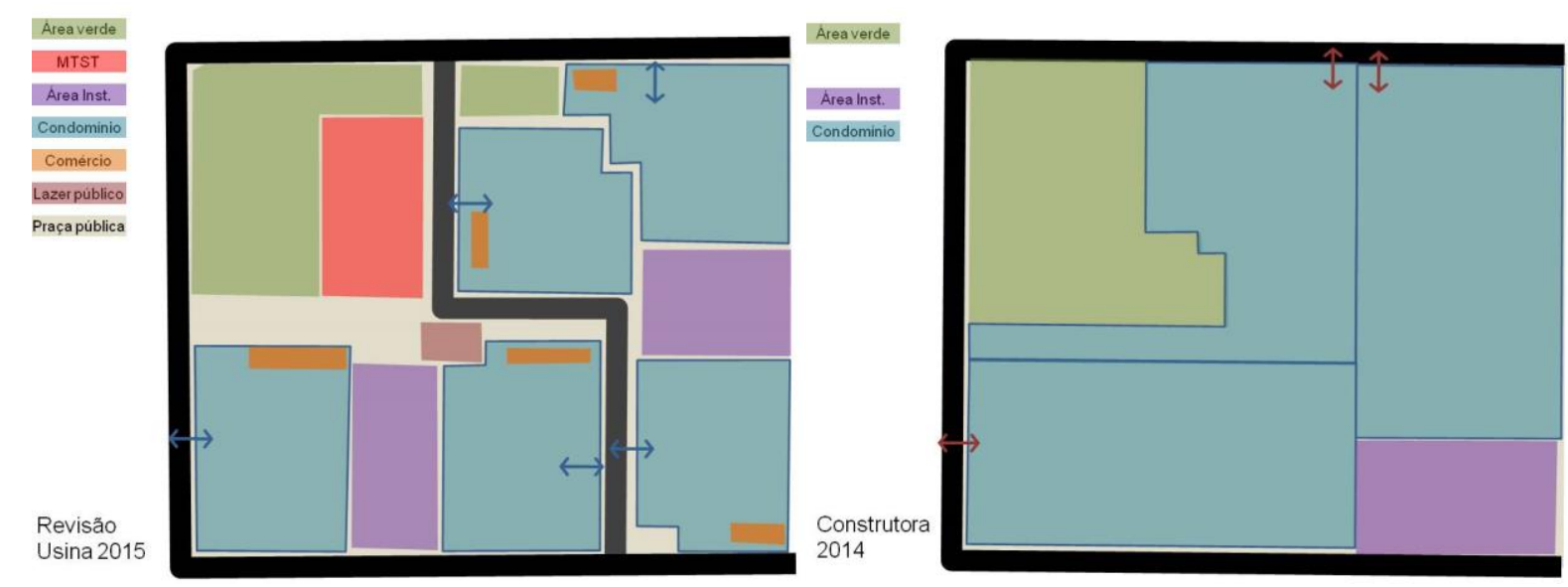

Figuras 18 a 21: Diagramas comparativos entre os projetos. Fonte: arquivo da Usina.

${ }^{25}$ Entre eles, Ruy Mauro Marini, da POLOP (Organização Revolucionária Marxista Política Operária); e Sérgio Ferro, na ALN (Aliança Libertadora Nacional).

Dialektiké, v. 1, 2016. p. 52-78 


\section{REFERÊNCIAS}

BARAVELLI, J. E.. Trabalho e Tecnologia no Programa MCMV. Tese de Doutorado, FAU USP. São Paulo: 2014. Orientação de Ermínia Terezinha Menon Maricato.

CAMARGO, Camila Moreno. Minha Casa Minha Vida Entidades: entre os direitos, as urgências e os negócios. Tese de Doutorado, IAU-USP. São Carlos: 2016. Orientação de Cibele S. Rizek.

FERRO, Sérgio. Arquitetura e Trabalho Livre. São Paulo: CosacNaify, 2006.

GUERREIRO, Isadora de Andrade. CEUs: Potencialidades e Contradições. Trabalho Final de Graduação, São Paulo, FAU-USP, 2006. Orientação: Vera Maria Pallamin.

HARVEY, David. O novo imperialismo. São Paulo, Editora Loyola, 2004. Tradução de Adail U. Sobral e Maria S. Gonçalves.

. "The Right to the city". In: New Left Review, no 53, set-out 2008.

MARINI, Ruy Mauro. "Dialética da Dependência”. In: TRASPADINI, R.; STEDILE, J.P. [orgs.]. Ruy Mauro Marini: Vida e Obra. São Paulo: Editora Expressão Popular, 2005 [1973].

MARX, Karl. O Capital - Crítica da Economia Política. São Paulo: Editora Abril, 1983 [1867]. Tradução de Regis Barbosa e Flávio R. Kothe.

PAULANI, Leda. Brasil Delivery: servidão financeira e estado de emergência econômico. São Paulo: Boitempo Editorial, 2008.

RANCIÉRE, Jacques. O desentendimento: política e filosofia. São Paulo: Editora 34, 1996.

RICCI, Rudá. Lulismo: da era dos movimentos sociais à ascensão da nova classe média brasileira. Brasília: Fundação Astrojildo Pereira; Rio de Janeiro: Contraponto, 2013 [2010].

SINGER, André. Os sentidos do Lulismo - reforma gradual e pacto conservador. São Paulo: Companhia das Letras, 2012.

Cutucando onças com varas curtas: 0 ensaio desenvolvimentista no primeiro mandato de Dilma Rousseff (2011-2014). In: Revista Novos Estudos Ceprab, no 102, pp. 4371, Julho de 2015. 